\title{
THE DISPUTE OF THE MONTHS IN SURETH AND ITS EAST-SYRIAC VORLAGE
}

\author{
AlessAndRo MENGOZZI \\ UNIVERSITÀ DEGLI STUDI DI TORINO
}

\begin{abstract}
In 1896 Lidzbarski published a Sureth (Christian NorthEastern Neo-Aramaic) version of the Dispute of the Months, as preserved in the ms. Berlin 134 (Sachau 336). The text is here republished with an English translation and compared with its Classical Syriac Vorlage. For the purpose of comparison, a provisional critical edition of the East-Syriac text in the classical language has been prepared on the basis of five manuscripts. The East-Syriac (and Sureth) version contains fewer references to Biblical and Christian culture than the West-Syriac text, as published by Brock in 1985, and appears to be a folk ballad with a few Christian motifs rather than a liturgical hymn. The text was attributed to the late 13th-century poet Khamis bar Qardahe and has been preserved in a couple of manuscript witnesses of the second part of his Diwan.
\end{abstract}




\section{WITNESSES}

In 1896 Lidzbarski published a Sureth (Christian NorthEastern Neo-Aramaic) version of the Dispute of the Months. ${ }^{1}$ In the present paper I intend to republish this text with an English translation and with a provisional edition of its East-Syriac Vorlage.

The Sureth text is preserved in a miscellaneous multilingual manuscript of the Berlin Sachau collection (Berlin 134, Sachau 336), ${ }^{2}$ written in 1883 by the copyist Fransi (Francis) Mèrī of Telkepe, a major Chaldean center near Mosul. The same copyist wrote a number of other Sureth manuscripts of the Sachau collection, which bears witness to the interest of Eduard Sachau in the languages spoken in northern Iraq and south-eastern Turkey. Berlin 134 is a good example of Sachau's choices in collecting texts. ${ }^{3}$ It contains:

1. a Kurdish Garshuni erotic poem; ${ }^{4}$

1 Mark Lidzbarski, Die neu-aramäische Handschriften der Königlichen Bibliothek zu Berlin (Weimar: Emil Felber, 1896), vol. 1, 442-6 (Sureth text and Arabic transl. by J. Shamir), vol. 2, 344-7 (German transl.).

2 Eduard Sachau, Verzeichniss der syrischen Handschriften der Koniglichen Bibliothek zur Berlin (Berlin: A. Asher \& Co., 1899), 437-42. A digital copy of the manuscript is available on the website of the Staatsbibliothek zu Berlin - Preußischer Kulturbesitz (Germany): Sammlung von Gedichten, Hochzeitsliedern und Geschichten, 1883.

${ }^{3}$ On Sachau's preferences and criteria in collecting Neo-Aramaic texts, see Francesca Bellino and Alessandro Mengozzi, "Geographical 'Ağäib in a Neo-Aramaic Manuscript of the London Sachau Collection." (Le Muséon 129:3-4 [2016]), 423-8 and Alessandro Mengozzi, "D'Ahiqar au tapis volant du roi Salomon, des mirabilia géographiques à Sindbad le marin en araméen moderne : adab et recherche orientaliste à la fin du XIXème siècle," in Actes du colloque international "L'adab, toujours recommencé : Origines, transmission et métamorphoses 》 (Paris, IISMM et INALCO, Jeudi 1er-Samedi 3 décembre 2016), ed. Francesca Bellino, Catherine Mayeur-Jaouen, and Luca Patrizi.

${ }^{4}$ On Kurdish Garshuni, see George Anton Kiraz, Tūrrās Mamllā. A Grammar of the Syriac Language, vol. 1 Orthography (Piscataway, NJ: Gorgias Press, 2012), 306-9, based on a text in serto script. On Kurmanji Kurdish in East-Syriac script, see Mustafa Dehqan, "A Kurdish Garshuni Version of 
2. Sureth erotic triplets; ${ }^{5}$

3. the famous Sureth poem by David the Blind on the Virgin Mary (b-shemmà d-bäbā $w$-bronä), which is a kind of national anthem for the Chaldeans of the plain of Mosul; ${ }^{6}$

4. the Story of Ahiqar ${ }^{7}$ and

5. Aesopic fables in Classical Syriac;

6. Sureth poems:

6.a The Dispute of the Months,

6.b The Dispute of Gold and Wheat,

6.c The Girl Mámoy Loved by a Bishop in Azerbaidjan,

6.d The Dispute of Cup, Jar and Wineskin,

6.e Satan and the Sinful Woman, ${ }^{8}$

Mem û Zîn" (Gerdûn 11 [2016]), 5-10 and Idem, "Sachau 204: A Kurdish Garshuni Poem" (Manuscripta Orientalia 22 [2016]), 68-70.

${ }^{5}$ Fabrizio A. Pennacchietti, "Zmiryata d-rawe: "stornelli" degli aramei kurdistani," in Scritti in onore di Giuliano Bonfante (Brescia: Paideia), vol. 2, 647-8 is still the most precise description of this genre and its Sitz im Leben. An up-dated bibliography can be found in Alessandro Mengozzi, "That I might speak and the ear listen to me!': On Genres in Traditional Modern Aramaic Literature" (Journal of Semitic Studies 57:2 [2012]), 327-9.

6 Alessandro Mengozzi, "Religious Poetry in Vernacular Syriac from Northern Iraq," in Idem, Religious Poetry in Vernacular Syriac from Northern Iraq (17th-20th Centuries). An Anthology, CSCO, Scriptores Syri 241 (Leuven: Peeters, 2011), xv.

7 On versions and fortune of Ahiqar, see Riccardo Contini and Cristiano Grottanelli (eds.), Il saggio Abiqar: Fortuna e trasformazione di uno scritto sapienziale. Il testo più antico e le sue versioni (Brescia: Paideia, 2005). An up-dated bibliography on the various Neo-Aramaic versions can be found in Alessandro Mengozzi, "D'Ahiqar au tapis volant du roi Salomon".

8 Alessandro Mengozzi, "A Neo-Aramaic Version of the Soghitha of the Sinful Woman and Satan," in Malphono w-Rabo d-Malphone. Studies in Honor of Sebastian P. Brock, ed. George Anton Kiraz (Piscataway, NJ: Gorgias Press, 2008). 
6.f Simon Magus and Simon Peter, ${ }^{9}$

6.g The Cherub and the Thief, ${ }^{10}$

6.h Mary and the Gardener, ${ }^{11}$

7. the prose story of a Duenna (kabrämānā) and a Young Prince. $^{12}$

Lidzbarski published the Sureth texts of the three dispute poems: The Dispute of the Months, The Dispute of Gold and Wheat and The Dispute of Cup, Jar and Wineskin, the latter preceded by a short Classical Syriac dialogue poem of a new friend who asks to be admitted to a company of drinkers. ${ }^{13}$ He copied en face the Arabic translation by Jeremiah Shamir, who was the key

${ }^{9}$ Alessandro Mengozzi, "Simon Magus and Simon Peter in Rome. The Sureth Version of a Late East-Syriac Hymn for the Commemoration of Saints Peter and Paul" (Kervan 22 [2018]), 65-90.

10 The text was published by Eduard Sachau, "Über die Poesie in der Volksprache der Nestorianer" (Sitzungsberichte der königlich-preussischen Ak. der W. zu Berlin XI:8 [1896]),179-215 and re-published, together with two other Sureth versions, by Fabrizio A. Pennacchietti, Il ladrone e il cherubino. Dramma liturgico cristiano orientale in siriaco e neoaramaico (Torino: Silvio Zamorani, 1993). On the fortune and Sitz im Leben of this text see Alessandro Mengozzi and Luca Basilio Ricossa, "The Cherub and the Thief on YouTube: An Eastern Christian Liturgical Drama and the Vitality of the Mesopotamian Dispute," (Annali dell'Istituto Orientale di Napoli 73 [2013]), 49-65.

11 Alessandro Mengozzi, "A Sureth Version of the East-Syriac Dialogue Poem of Mary and the Gardener" (Kervan, forthcoming).

12 An Arabic translation of this Sureth story, by Jeremiah Shamir (see n. 14, below), can be found in the ms. Berlin 133 (Sachau 200), 58b-63b. A more recent and elaborate Sureth version is added at the end of a manuscript collection of hagiographic texts, dated 1937 (ms. 135 of the Chaldean Church of the Sacred Heart of Telkepe, near Mosul: QACCT 135 in the database of www.hmml.org), where it is entitled Story of Sayf al-Masih, son of the king of Rumia, and Ë̈ubatnam, daughter of the King of France. The ms. contains 21 lives of martyrs and saints and the last two texts are the stories of Ahiqār and Sayf al-Masīh. 13 of the other 19 texts were copied from Paul Bedjan, Vies des saints en langue chaldéenne moderne (Paris-Leipzig: Harrassowitz, 1912).

13 Mark Lidzbarski, Die neu-aramäische Handschriften, vol. 1, 442-57 (Sureth text and Arabic transl.), vol. 2, 344-56 (German transl.). 
figure for Sachau's activities as a collector of texts and purchaser of manuscripts in northern Iraq. ${ }^{14}$

In a footnote at the beginning of his German translation of the disputes, Lidzbarski observes that this kind of $W$ ettstreite appear to be rather popular among the East Syrians, whom he called the "Nestorians", and that they also occur in Arabic literature, where the Dispute of Pen and Sword appears to be one of the favorite themes. ${ }^{15}$

14 See Rifaat Ebied, "A collection of letters in Syriac and Arabic addressed to Eduard Sachau (1845-1930)" (ARAM 21 [2009]), 79-105 and Rifaat Ebied and Nicolas Al-Jeloo, "Some further letters in Syriac, NeoAramaic and Arabic addressed to Eduard Sachau by Jeremiah Shāmīr" (Journal of Assyrian Academic Studies 24 [2010]), 1-45. Shamir's translation of the disputes is preserved in the ms. Sachau 343, 14b-16b.

15 Mark Lidzbarski, Die neu-aramäische Handschriften, vol. 2, 344. On the problem of the origin of the Classical Arabic munäzara as a learned literary genre, see John N. Mattock, "The Arabic Tradition: Origin and Developments," in Dispute Poems and Dialogues in the Ancent and Mediaeval Middle Near, ed. Gerrit Jan Reinink and Herman L.J. Vanstiphout (Leuven: Peeters, 1991), 153-63. A more popular form of poetic dispute would seem to be, in modern times, a vernacular genre cultivated in oral traditions throughout the Middle East and the Arab World: Henri Massé, "Du genre littéraire 'Débat' en arabe et en persan" (Cahiers de Civilisation Médiévale 4 [1951]), 144-147; Urbain Bouriant, Chansons populaires arabes en dialecte $d u$ Caire (Paris: Leroux, 1893) and Enno Littmann, "Neuarabische Streitgedichte," in Festschrift zur Feier des Zweihundertjährigen Bestehens der Akademie der Wissenschaften in Göttingen, II Philologisch-historische Klasse (Berlin: Springer, 1951), 26-66 (Egyptian Arabic); Clive D. Hole, "The Rat and the Ship's Captain: A dialogue poem from the Gulf, with some comments on the social and literary-historical background of the genre" (Studia Orientalia 75 [1995]), 101-20; Idem, "The Dispute of Coffee and Tea: A debate-poem from the Gulf," in Tradition and Modernity in Arabic Language and Literature, ed. J.R. Smart (London: Curzon Press, 1996); Idem, "The Debate of Pearl-Diving and Oil Wells: A poetic commentary on socio-economic change in the Gulf of the 1930s" (Arabic and Middle Eastern Literatures 1 [1998]), 87-112; Mark Wagner, "The Debate Between Coffee and Qāt in Yemeni Literature" (Middle Eastern Literatures 8 [2015]), 121-49; see also the playful, almost childish, Sureth dialogue poem of The Boys and the Tea-Kettle: L. Yaure, "A Poem in the Neo-Aramaic Dialect of Urmia" (Journal of Near Eastern Studies 16 [1957]), 73-87 and Alessandro Mengozzi, "Neo-Aramaic Dialogue and Dispute Poems. The 
Thanks to numerous studies and text editions by Sebastian Brock, hymns that have the structure of dialogue or dispute poems form one of the best-known genres in Classical Syriac literature. ${ }^{16}$ In 1985, Brock published and translated into English a number of Classical Syriac and Jewish Aramaic poems concerning the months of the year. ${ }^{17}$ Among them we find the Dispute of the Months and the Dispute of Gold and Wheat. For the Dispute of Gold and Wheat, Brock had at his disposal only

Various Types," in the proceedings of the international conference Disputation Poems in the Near East and Beyond. Ancient and Modern, held in Madrid 12-13 July 2017, ed. Enrique Jiménez (Berlin: De Gruyter, forthcoming).

${ }^{16}$ See, e.g., Sebastian P. Brock, Soghyāthā Mgabbyäthā (Glane: Monastery of St. Ephrem, 1982); "Dialogue Hymns of the Syriac Churches" (Sobornost. Eastern Churches Review 5:1 [1983]), 35-45; "Syriac Dialogue Poems: Marginalia to a Recent Edition" (Le Muséon 97 [1984]), 29-58; "Syriac Dispute Poems: The Various Types," in Dispute Poems and Dialogues in the Ancient and Mediaeval Near East, ed. Gerrit Jan Reinink and Herman L.J. Vanstiphout (Leuven: Peeters,1991), 109-19; "The Dispute Poem: From Sumer to Syriac" (Journal of the Canadian Society for Syriac Studies 1 [2001]), 3-10. An up-dated list of Syriac dialogue and dispute poems can be found in Sebastian P. Brock, Mary and Joseph, and other dialogue poems on Mary (Piscataway, NJ: Gorgias Press, 2011), 97-104.

17 Sebastian P. Brock, "A Dispute of the Months and Some Related Syriac Texts" (Journal of Semitic Studies 30:2 [1985]), 181-211. A short version (A dispute arose) and a complete Dispute of the Months (All months gathered, with the same opening formula of the Syriac Dispute) from the Cairo Genizah were published by Alphons S. Rodrigues Pereira, Studies in Aramaic Poetry (c. 1000 B.C.E. - c. 600 C.E.) (Assen: Van Gorcum, 1997), 310-2 (Aramaic text), 392-5 (English transl.). Six Jewish Palestinian Aramaic disputes of the months are listed in Michael Rand, "An Aramaic Dispute between the Months by Sahlan ben Avraham” (Melilah: Manchester Journal of Jewish Studies 9 [2012]), 102-4, with a bibliography, which, however, does not include Rodrigues Pereira. Some of these poems are now translated into English by Laura Suzanne Lieber, Jewish Aramaic Poetry from Late Antiquity (Leiden: Brill, 2018), 126-42, among other texts on the months and the primacy of Nisan. For a comparison of the disputes of the months as attested in Classical Syriac and Jewish Palestinian Aramiac, see Alessandro Mengozzi, "Syrische Streitgedichte als mündliche Dichtung," in the proceedings of the 10. Deutscher Syrologentag (Berlin, 30/05-2/06 2018), ed. Shabo Talay, forthcoming. 
the late East-Syriac version preserved in the manuscript Cambridge Add. 2820 and the Sureth free poetic adaptation published by Lidzbarski. For the Dispute of the Months, Brock chose as the base text for his edition the ms. Add. 17141 of the British Library (henceforth A; dated to the eighth-ninth century on paleographic grounds). This manuscript is one of the earliest West Syriac collections of madräsha and soghithā hymns, which are intended for liturgical use but are not yet ordered according to the liturgical calendar. Brock collated the text of A with three other versions of the Dispute. The first sixand-a-half verses of the poem are quoted by Anton of Tagrit (9th century) in his handbook of rhetoric as an example of personification (R). As for the Dispute of Gold and Wheat, Brock had at his disposal the late East Syriac (B) and the Sureth (S) versions of the Dispute of the Months.

When they are available, the variants of the quotation by Anton of Tagrit $(\mathrm{R})$ are often preferable to the text preserved in the West-Syriac version of A. In some cases, the text of R corresponds to the late East Syriac version (B). The East-Syriac version is meanwhile known from witnesses other than $B$, which was the only East-Syriac manuscript available to Brock. For the present, provisional edition of the East-Syriac text, I collated four manuscripts and the text of an early 20th-century Alqosh manuscript as published by Shleymon Hoshaba in his 2002 edition of the Book of Khamis bar Qardahe .

- Baghdad Church of the East 6 (1719), 214-6

- Baghdad Church of the East 10 (19th cent.?), 226-32 18

18 The manuscripts of the Archbishopric of the Church of the East in Baghdad were photographed in the context of a 2005 project for the preservation and documentation of Syriac manuscripts: Hubert Kaufhold, "Über einige Projekte der Digitalisierung syrischer Handschriften" (Oriens Christianus 90 [2006]), 210-6. Since the folios of this manuscript are not numbered, I refer to page numbers as given in the jpeg file names. 
- Cambridge Add. 2820 (Telkepe 1881), 98a-99b (B; collated by Brock)

- Chaldean Monastery 921 (Alqosh 1906) ${ }^{19}$

- Trichur 25 (19th-20th cent.?), 86a-b

The East-Syriac dispute poems were included in two types of manuscript collections of soghyäthä: in books of soghyatha ordered according to the liturgical calendar (Baghdad 6) and in late manuscripts that preserve the second part of the Book of Khamis (Baghdad 10, Chaldean Monastery 921, Trichur 25). In this second type of manuscripts, the disputes are thus implicitly attributed to the late 13th-century East Syriac poet Khamis bar Qardahe..$^{20}$ Cambridge Add. 2820 is somewhat in between the two types of manuscripts, in that it contains soghyatha for liturgical use as well as a number of poems of the Khamis collection.

The East-Syriac copies most likely derive from a common archetype and there is very little, almost exclusively orthographic variation among them. The Sureth version clearly reflects a text similar to the East-Syriac archetype. The translator renders the seven syllable lines of the original in lines

${ }^{19}$ Shleymun I. Hoshaba (ed.), Khamis bar Qardahēe, Mêmrē w-mush̆äthā (Nuhadra: Prisatha da-N̦̣ivin, 2002), 195.

20 The second part of the Book of Khamis contains sogbyatha (series of quatrains of seven syllable lines, often linked by aphabetic acrostic), monorhyme poems (in the late East-Syriac manuscripts they are called mémrê) and quatrains (called $\left.\operatorname{tar}^{(} \hat{)}\right)$. It is preserved only in a few manuscripts. Anonymous poems and poems by other authors were added in both parts of the Book. On its structure and history, see Alessandro Mengozzi, "Persische Lyrik in syrischem Gewand. Vierzeiler aus dem Buch des Khamis bar Qardahe (Ende 13. Jahrhundert)," in Geschichte, Theologie und Kultur des syrischen Christentums. Beiträge zum 7. Deutschen Syrologie-Symposium in Göttingen, Dezember 2011, ed. Martin Tamcke and Sven Grebenstein (Wiesbaden: Harrassowitz, 2014), 155-76 and Idem, "The Book of Khamis bar Qardahe: History of the Text, Genres and Research Perspectives," in Syriac Encounters. Papers from the Sixth North American Syriac Symposium, Duke University, 26-29 June 2011, ed. Maria Doerfler, Emanuel Fiano, and Kyle Smith (Leuven: Peeters, 2015), 415-36. 
of seven or eight syllables, possibly compatible with the melody according to which the hymn was sung. However, in accordance with the taste of Late Syriac and Modern Aramaic poetry, he stabilizes as AAAA the rhyme that in the original occurs sparsely and in rather irregular patterns (1b-1d, 3a-3b3d, 4a-4b-4c, 6a-6b, 7a-7b, 7c-7d, 15b-15d. 16a-16b).

The scribe of the Sureth version uses the customary phonetic rather than phonological spelling of northern Iraqi manuscripts. For example, he interchangeably uses $e$ and $\bar{e}, a$ and $\bar{a}$ : compare, e.g., $12 \mathrm{a}$ pletle... tamoz with $14 \mathrm{a}$ tàmozplètle. One remarkable feature of this text is the hypercorrect use of the linea occultans for matres lectionis such as y in (12c) and

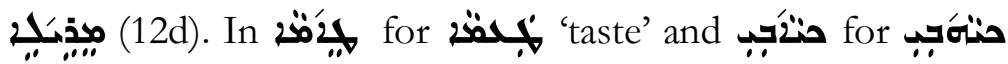
'they give' (13b) the system of historical spelling and linea occultans clearly seizes up. The word ọُ (15a) seems to be an odd combination of the vowels of the historical spelling (تشتئi)

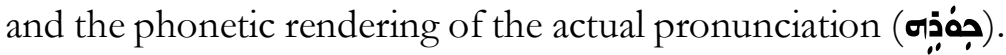

\section{Syriac Dispute Poems as Oral Poetry}

If we compare the East-Syriac version of the Dispute of the Months, including its Sureth poetic adaptation, with the WestSyriac text (A) published by Brock, ${ }^{21}$ we find a higher degree of textual variation, as is typical of oral tradition.

In both versions, the Syriac Dispute of the Months appears as a complete calendar in verses, inserted in the incomplete frame of a Mesopotamian dispute. ${ }^{22}$ The deity who plays the role of

${ }^{21}$ Sebastian P. Brock, “A Dispute of the Months”, 189-93. See also Sebastian P. Brock, Soghyāthā Mgabbyāthā (Glane: Monastery of St. Ephrem, 1982), 108-10.

22 See Enrique Jiménez, The Babylonian Disputation Poems (Leiden: Brill, 2017) on the Mesopotamian dispute and its incredible diffusion in literary traditions that have been directly or indirectly in contact with the ancient Mesopotamian civilization. The format of the Mesopotamian dispute is characterized by the following features: 1 . poetic form, 2. tripartite structure (introduction, disputation proper, and conclusion), 3. few or no narrative 
arbiter and judge in the Mesopotamian dispute is here replaced by the personification of the year, who sits among the months to judge their case (v. 1). However, the prologue in heaven is not closed at the end by the epilogue, where the winner is usually proclaimed in the Mesopotamian dispute.

As is typical for oral poetry, the poetic language of the text is formulaic. The term "formula" is here intended in the technical sense that has been developed and refined in the context of the study of oral traditions. ${ }^{23}$ Formulas and, more generally, repetition create a rhythmical text that is easy to memorize, recite, and improvise for a vocal performer and easy to be decoded and understood by the audience. The Dispute of the Months is built on formulas that make the structure of the text transparent. They mark the rotation of characters on stage, introduce the name of the month that is going to speak, and repeat the name of the month that is leaving the scene. Moreover, the months usually start their speech using formulas

portions, 4. usually inanimate disputants, 5. supremacy or precedence as main matter of debate.

23 The definition of the formula as "a group of words employed under the same metrical conditions to express a given essential idea" (John M. Foley, Traditional Oral Epic. The Odyssey, Beowulf, and the Serbo-Croatian Return Song [Berkeley: University of California Press, 1990], 2, n. 3) and consequently the description of its function as a metrical filler, a mnemotechnic device and a tool for improvisation, go back to the studies of Milman Parry (1902-1935) and Albert Lord (1912-1991) on ancient Homeric and modern Serbo-Croatian epics. From the point of view of cultural anthropology (orality vs. literacy) and literary criticism, more recent studies on oral tradition have highlighted other and more important functions of formulas in the aesthetics and social meanings of oral texts, i.e. texts that are orally composed (improvised) and transmitted and preserved — at least partly — by memory. Oral texts may be composed and preserved in written form, but they are nevertheless supposed to be performed orally, by a human voice. See, e.g., the anthropological and philosophical approach of Marshall McLuhan's pupil Walter Jackson Ong, Orality and Literacy. The Technologizing of the Word (New York: Routledge, 1982) and the cultural and literary approaches in a miscellaneous volume such as Alger N. Doane and Carol Braun Pasternack, Vox Intexta. Orality and Textuality in the Middle Ages (Madison, WI: University of Wisconsis Press, 1991), largely inspired by the studies of Paul Zumthor (1915-1995) on medieval European literatures. 
that contain the semiotic pair "to speak, tell" and "to give ear, listen" that verbalizes and stylizes the poet-audience interaction in oral/aural transmission: ${ }^{24}$ e.g., "Nisan went out and Iyyar came in to say these words: “... Come, give ear and listen!"” (v. 5). ${ }^{25}$

The West-Syriac version has also a refrain, construed with the combination of formulas occurring elsewhere in the text: 'Come and listen to what the months have to say and give praise to their Creator!' (transl. by Brock 1985). The refrain points to a choral performance of the text in the context of liturgy, which is a very specific performance arena of oral poems: no matter how they are composed and preserved, hymns are supposed to be performed vocally.

Compared to the 23 verses of the West-Syriac version (A), the seventeen verses of the East-Syriac version appear to have or, perhaps, to have preserved the character of a simpler folk ballad, rather than a liturgical hymn concerned with Biblical references or theological and exegetical matters. In the EastSyriac version we do not find vv. 8 and 21-23 of A, that contain explicit references to Mary, Jesus, John the Baptist, and his mother Elisabeth and are thus possibly added to a text that

24 Paul Zumthor, La lettre et la voix. De la "littérature" médiévale (Paris: Éditions de Seuil, 1987), 42 : "L'emploi du couple dire-ouïr a pour fonction manifeste de promouvoir (fût-ce fictivement) le texte au statut de locuteur et de désigner sa communication comme une situation de discours in praesentia."

25 I suspect that the formula مقّه 'and his voice raises (raising his voice $>$ loudly)' (2a in the East-Syriac version and $2 \mathrm{a}$ and $5 \mathrm{a}$ in the WestSyriac version of the Dispute of the Months) does not have a descriptive content, but it is used as a metrical filler, pretty much as the famous Homeric formula हैं $\varepsilon \alpha \alpha \pi \varepsilon \rho o ́ \varepsilon \nu \tau \alpha$ 'winged words', that introduces all kind of speech: George Miller Calhoun, "The Art of Formula in Homer" (Classical Philology 30 [1935]): 215-27 and Milman Parry, “About Winged Words" (Classical Philology 32 [1937]): 59-63. 
otherwise speaks of seasons, fruits, peasants' life, the economy, even war (sickles as swords), and the power of a king.

The only Christian themes preserved by both versions are Christmas and Jesus' Baptism in the closing verses and the cross carried by the months $\mathrm{Ab}$ and Illul (August and September) on their shoulders (v. 14 in the East-Syriac and v. 16 in the West-Syriac text), as a possible allusion to the feast of the Holy Cross, celebrated respectively on September 13th and 14 th by the East and West Syrians.

The absence in the East-Syriac version of the Christian characters mentioned in the West-Syriac text and the fast pace of its shorter text make the dispute, in which every month praises itself, a kind of prelude for a Christmas carol. The increasing tension of the discussion focuses all the attention on the final verse, in which December and January defend themselves from the other months' mockery and reply that precisely in them, which are sterile and seemingly insignificant for agriculture and human economy, Jesus was born and was baptized. "By His birth He made all things rejoice": Divine economy reverses the fortunes of the winter months that cannot let people rejoice with their flowers and fruits.

The differences in wording and text character of the two versions of the Dispute of the Months can be perfectly understood in the context of the oral and mixed (written and oral) traditions in which they have been produced, preserved, and transmitted. Textual variation should be interpreted not so much in the negative sense of alteration, contamination, or distortion of an original, but as a product of the creative process typical of oral poetry. Each version of an oral text differs from the other, not only because songs are continuously reshaped by the skills of the performers (memory, improvisation, free recombination of formulas, motifs, stylistic, rhythmical and melodic figures, virtuosity...) but also because they are adapted to different audiences, listeners, and performance arenas. A traditional repertoire of themes (description of nature and human society or references to the Bible in our dispute) are combined in calendars in which the 
religious elements come more or less to the fore according to the type of texts that the author wants to bring into play, in balance between the needs and preferences of liturgy and pedagogical entertainment. ${ }^{26}$

The West-Syriac text is more clearly a hymn, whereas the East-Syriac text and its Sureth poetic translation seem to reduce explicit references to Christian culture, so as to preserve themes and atmosphere of more archaic folk ballads, not necessarily Christian, and highlight, by contrast, the final verse on Christmas. It is difficult to say which version of the text is earlier. Both ultimately derive from the same oral tradition.

\section{THE EAST-SYRIAC TEXT}

Another poem on the months

The months of the Year gather together

to tell the story of their products.

The Year is seated like a lord

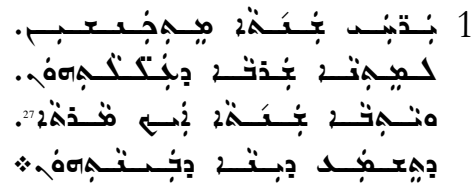

to listen to the case that came up among them.

Nisan came in and raised his voice

to say these words:

'The Year is not as pleased with you all,

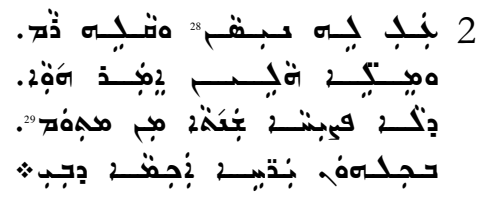
months, as he is with me.

26 Alessandro Mengozzi, "Syrische Streitgedichte als mündliche Dichtung".

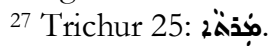

28 Baghdad 10, Cambridge 2820: كبفم, wherever it occurs.

${ }^{29}$ Cambridge 2820: مبم مصمفه 
In me new things take place and good tidings are announced.

In me the Lord adorns the mountains

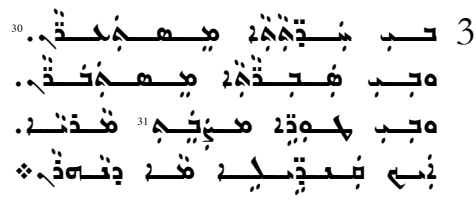

like candles when they give light.

In me the cycles of the sun extend

and the hours of the day grow longer.

In me swallows sing

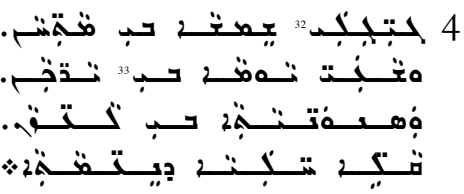

melodies of sweet notes.'

Nisan went out and Iyyar came in

to say these words:

'Go, Nisan! You are not better than me.

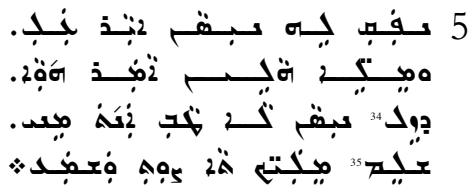

Stop your chatter! Come, give ear and listen!

In me bloom much-desired roses,

in me sweet scents send forth their fragrance.

In me a crown of the Year is

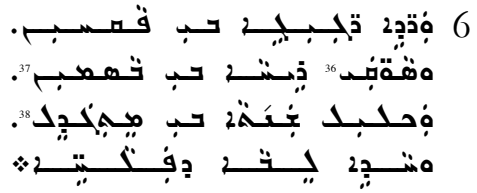
woven

and the hearts of labourers rejoice.

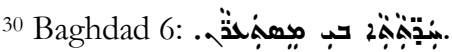

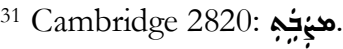

32 Cambridge 2820: يجبت

33 Baghdad 10, Trichur 25, Hoshabba (2002: ms.): بִ.

34 Hoshabba (2002):

35 Cambridge 2820: عبارج, wherever it occurs.

36 Hoshabba (2002):

37 Baghdad 6: بُنْمبr.

38 Cambridge 2820: تحدِ
} 
In me the ears of corn grow tall in the field,

blades grow thick and tall, when beards grow on the tips of the ears

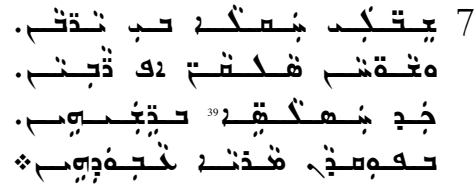

at the command of the Lord their Maker.'

Iyyar went out and Haziran came in

to say these words:

'Go, Iyyar! You are not better than me.

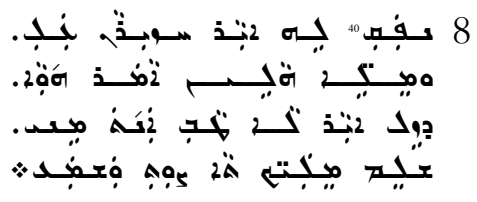

Stop your chatter! Come, give ear and listen!

All creatures gather together in me

and come forth as from the bridal chamber.

Like servants before their
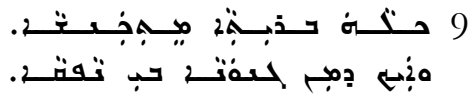

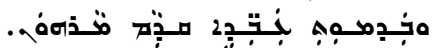

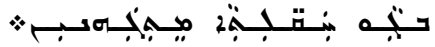
master

they bow down in the fields.

The beauty of their sheaves shines

like glittering swords.

The heart of the widow rejoices

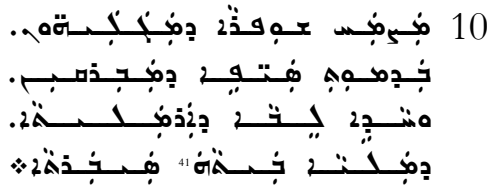

whose house is full of provisions.

Sheaves are piled high in me heap on heap in the granaries,

whence the poor may eat, be satiated

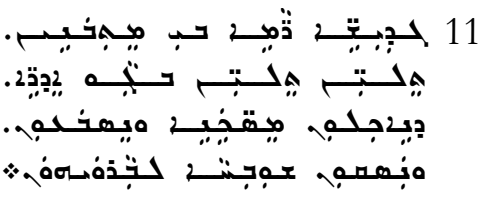
and glorify their Creator.'

\footnotetext{
39 Cambridge 2820: بنقفم:25.

40 Trichur 25: كقَّ.

41 Baghdad 6: بَتْ 2
} 
Haziran went out and

Tammuz came in

to say these words:

'Go, Iyyar! You are not better than me.

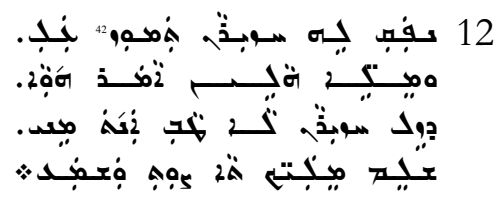

Stop your chatter! Come, give ear and listen!

Sweet bunches grow ripe in me,

they give the taste of their sweetness,

quinces, pomegranates,

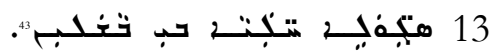

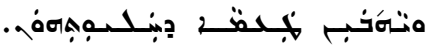

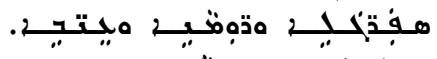

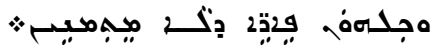

grapes,

and all of them with

innumerable fruits.'

Tammuz went out and $\mathrm{Ab}$ and Illul came in,

two months together.

They bore a cross on their shoulders.

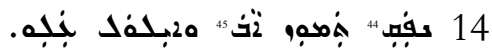
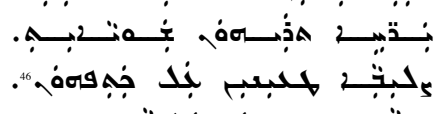

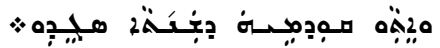

They came and bowed before the Year.

The two Teshris pressed the wine,

the pure oil of their produce, whence the poor may eat, be satiated

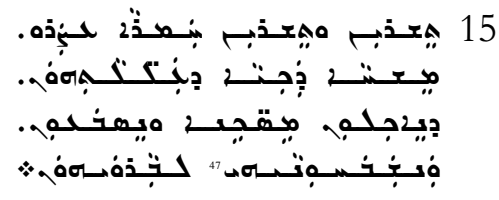

and glorify their Creator.

Then the months began to pour scorn on

the two Kanuns and said:

'Barren and desolate months,

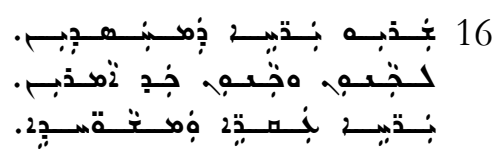

42 Trichur 25: הَم0.

43 Baghdad 6: بُبر.

44 Cambridge 2820: كفُبه.

${ }^{45}$ Cambridge 2820: 2ُنَ; Trichur 25:

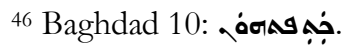

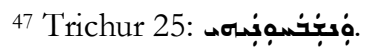


what do you have to say?'

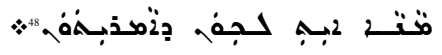

In reply they said:

'Our Lord's birth happened in us,

He was born in one and baptized in the other,

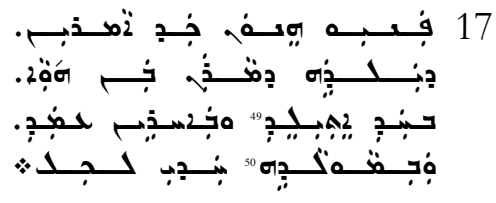
and by His birth He made all things rejoice.'

\section{The SureTH TeXT}

Another (poem) on the months of the year

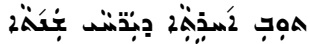

The months of the Year gathered together

to speak about their goods. They spoke to each other and showed their love.

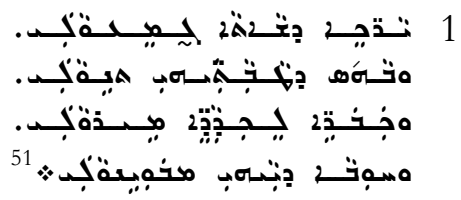

Nisan came in and came near and spoke these words:

He revealed that the year is not pleased with all his fellow months.

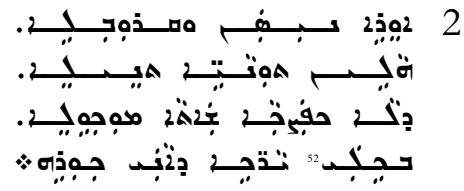

"In me new things are made new

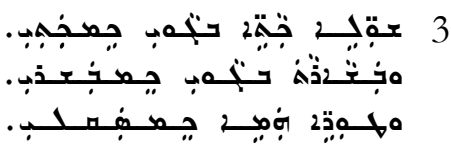

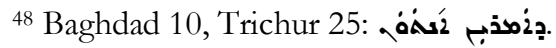

49 Cambridge 2820:

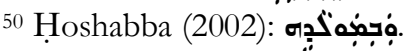

51 After v. 1 and 6, there is a mysterious blank line in the manuscript, with a centered rubric 2 מسב 2 'another (poem)', as if it marked the beginning of a new text.

בجمبد can be read as bkèlay 'they wept', but that clearly does not fit the context. More likely, it is a phonetic rendering of bkallay, with a shwalike pronunciation of the [u] of bkullay 'in all of them'. 
and good tidings are announced..$^{3}$

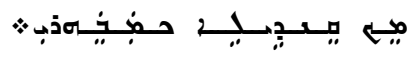

In me also the mountains adorn themselves ${ }^{54}$

like candles when they give light.

In me the cycles of the sun extend

and the hours of the day grow longer.

All swallows fly

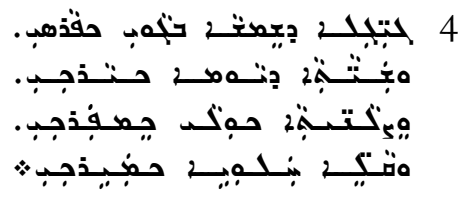

and prolong sweet melodies."

Nisan went out and Iyyar came in

to say these words:

"Go, Nisan!" and he drove him away.

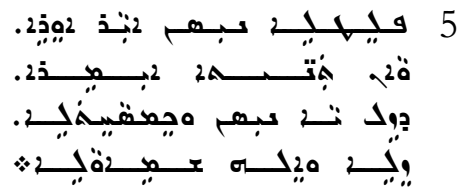

He went and listened to him.

"Much-desired roses are in me conceived ${ }^{s 5}$, and pleasant scents appear. Woven crowns in me are carried $^{66}$

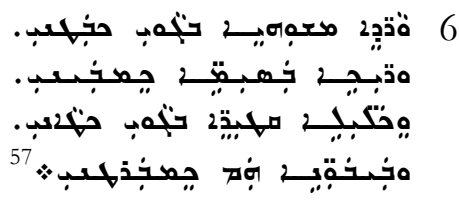

and flowers blossom too.

The ears of corn of the fields increase,

extend, spread and grow high. They bring forth ears of corn on their tips.

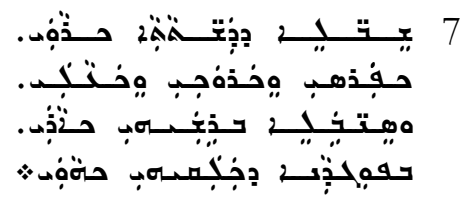

53 The third plural verbal forms can be interpreted as impersonal constructions with passive meaning: 'they announce good tidings' $>$ 'good tidings are announced'.

${ }^{54}$ Lit. 'mountains adorn'.

${ }^{55}$ Lit. 'roses conceive, get pregnant'.

${ }^{56}$ Lit. 'they carry, bear'.

57 As after v. 1, there is a mysterious blank line in the manuscript, with a centered rubric מגבנ2 'another (poem)', as if it marked the beginning of a new text. 
They are at the command of their creator."

Iyyar went out and Haziran came in

to say these words:

"Go, Haziran!" and he drove him away.

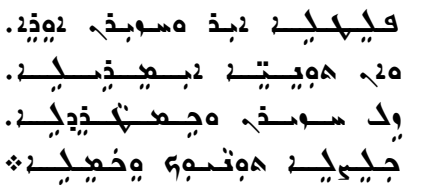

"Your speech has finished and come to an end"

"When all creation rises and goes outside in this day, out of bliss it praises the Heights

that gives peace and welfare

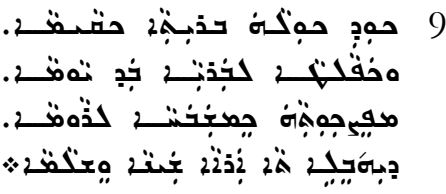
to the earth.

The beauty of their sickles lightens

like drawn swords. ${ }^{58}$

Their widows thanks to me rejoice

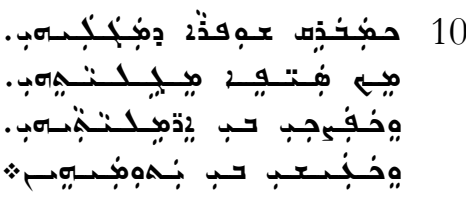

and their orphans thanks to me are nourished.

Sheaves are piled high in me and threshing floors are full. The poor receive their food and raise glory to God."

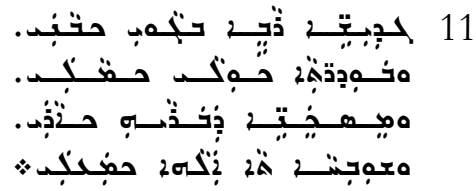

Haziran went out and Tammuz came in

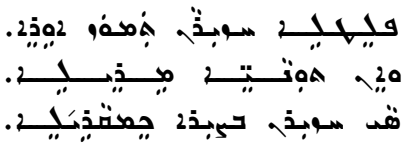
to say these words:

"Go, Haziran!" and called him poor.

58 With Shamir, Lidzbarski translates both magl-aybi (10a) and megèlyäthehi (10b) as 'their sickles', but a copula is missing in 10b: 'like swords [are] their sickles'. Alternatively, the second form maybe a participle of the verb mgäle 'to lay bare, uncover': mekh saypē mgulyäthè (?) 'like drawn swords' (?), but the possessive suffix is difficult to understand in this case. 
"Bow and genuflect in front of me!" He said to him.

"Vines in me ripen, and offer [their] sweet taste, grapes and quinces give pleasure

to all mouths that taste them."

Tammuz went out and $\mathrm{Ab}$ and Illul came,

two months together ${ }^{59}$.

They bore a cross on their shoulders.
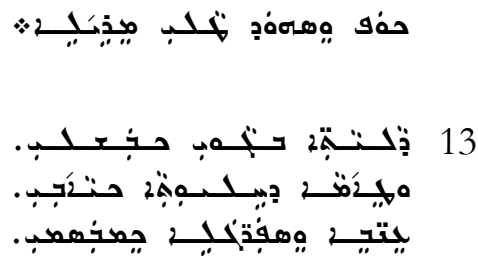

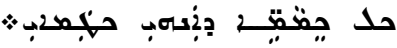

They glorified the creator of the year.

Teshri and his fellow came forward.

They showed the oil of their presses

and they provided for the needy.

The two Kanuns rebuked them.

When they were speaking so they called them sterile months.

They despised them greatly. "What do you have?" They said to them.

In reply they said to them that Our Lord's birth happened in them and he was baptized in the second of them.

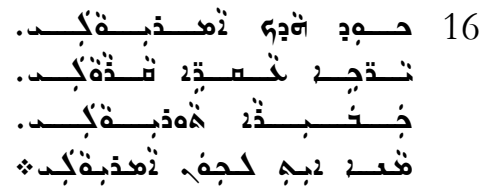

14
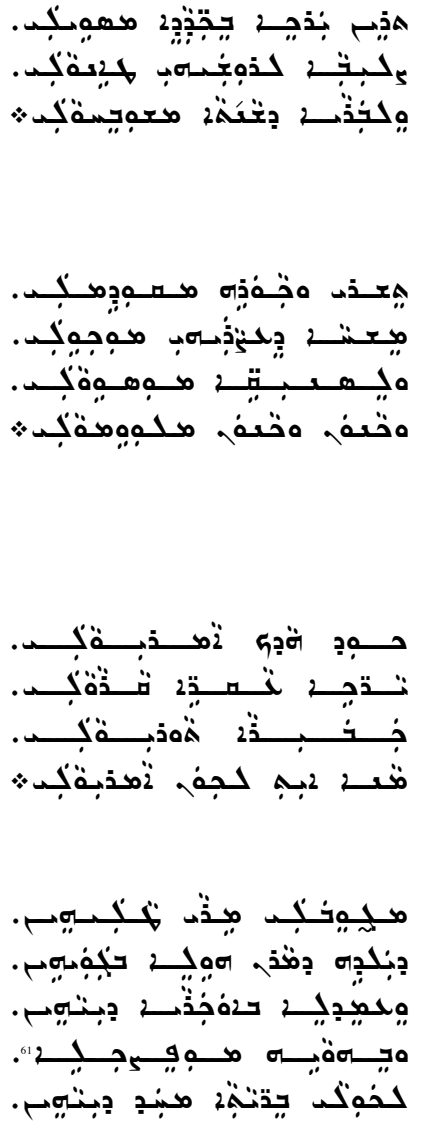

${ }^{59}$ Lit. 'the two months were similar to each other'.

61 Sic for מمويج2 or as a phonetic rendering of a different syllabic structure of the form. 
By his birth he made all creatures

rejoice from the first of them ${ }^{60}$,

so that they yell all with their

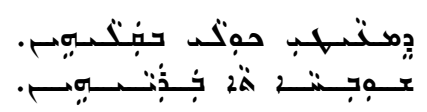

voices

glory to their creator.

Amen amen!

\section{BIBLIOGRAPHY}

Bedjan, Paul. Vies des saints en langue chaldéenne moderne. ParisLeipzig: Harrassowitz, 1912.

Bellino, Francesca, and Alessandro Mengozzi. “ Geographical 'A ğäib in a Neo-Aramaic Manuscript of the London Sachau Collection." Le Muséon 129:3-4 (2016): 423-56.

Bouriant, Urbain. Chansons populaires arabes en dialecte du Caire. Paris: Leroux, 1893.

Brock, Sebastian P. Soghyāthā Mgabbyāthā. Glane: Monastery of St. Ephrem, 1982.

Brock, Sebastian P. "Dialogue Hymns of the Syriac Churches." Sobornost. Eastern Churches Review 5:1 (1983): 35-45.

Brock, Sebastian P. "Syriac Dialogue Poems: Marginalia to a Recent Edition.” Le Muséon 97 (1984): 29-58.

${ }^{60}$ With Shamir, Lidzbarski translates mhad diyayhen as 'to the extreme limit (from Arabic hadd)'. I prefer to read it as 'from one (from Aramaic had) of them', which forms a kind of hysteron proteron with the preceding lines: 'He was baptised in the second of them [the second Kanun, i.e., January]. By his birth he made all creatures rejoice from the first of them [the first Kanun, i.e., December]'. Admittedly, 'first' should be qämāya rather than $x \bar{a}(<h \bar{a} \bar{d})$. 
Brock, Sebastian P. "A Dispute of the Months and Some Related Syriac Texts." Journal of Semitic Studies 30:2 (1985): 181-211.

Brock, Sebastian P. "Syriac Dispute Poems: The Various Types." In Dispute Poems and Dialogues in the Ancient and Mediaeval Near East, ed. Gerrit Jan Reinink and Herman L.J. Vanstiphout. Leuven: Peeters,1991.

Brock, Sebastian P. "The Dispute Poem: From Sumer to Syriac." Journal of the Canadian Society for Syriac Studies 1 (2001): 3-10.

Brock, Sebastian P. Mary and Joseph, and other dialogue poems on Mary. Piscataway, NJ: Gorgias Press, 2011.

Calhoun, George Miller. "The Art of Formula in Homer." Classical Philology 30 (1935): 215-27.

Contini, Riccardo and Cristiano Grottanelli (eds.). Il saggio Abiqar. Fortuna e trasformazione di uno scritto sapienziale. Il testo più antico e le sue versioni. Brescia: Paideia, 2005.

Dehqan, Mustafa. "A Kurdish Garshuni Version of Mem û Zîn.” Gerdûn 11 (2016): 5-10.

Dehqan, Mustafa. "Sachau 204: A Kurdish Garshuni Poem." Manuscripta Orientalia 22 (2016): 68-70.

Doane, Alger N. and Carol Braun Pasternack. Vox Intexta. Orality and Textuality in the Mddle Ages. Madison, WI: University of Wisconsis Press, 1991.

Ebied, Rifaat. "A collection of letters in Syriac and Arabic addressed to Eduard Sachau (1845-1930)." ARAM 21 (2009): 79-105.

Ebied, Rifaat and Nicolas Al-Jeloo. "Some further letters in Syriac, Neo-Aramaic and Arabic addressed to Eduard Sachau by Jeremiah Shāmīr." Journal of Assyrian Academic Studies 24 (2010): 1-45. 
Foley, John M. Traditional Oral Epic. The Odyssey, Beowulf, and the Serbo-Croatian Return Song. Berkeley: University of California Press, 1990.

Holes, Clive D. "The Debate of Pearl-Diving and Oil Wells: A poetic commentary on socio-economic change in the Gulf of the 1930s." Arabic and Middle Eastern Literatures 1 (1998): 87-112.

Holes, Clive D. "The Dispute of Coffee and Tea: A debatepoem from the Gulf'. In Tradition and Modernity in Arabic Language and Literature, ed. J.R. Smart. London: Curzon Press, 1996.

Holes, Clive D. 'The Rat and the Ship's Captain: A dialogue poem from the Gulf, with some comments on the social and literary-historical background of the genre." Studia Orientalia 75 (1995): 101-20.

Hoshaba, Shleymun I. (ed.). Khamis bar Qardaḥē, Mêmrē wmush̆äthā. Nuhadra: Prisatha da-Nșivin, 2002.

Jiménez, Enrique. The Babylonian Disputation Poems. Leiden: Brill, 2017.

Kaufhold, Hubert. "Über einige Projekte der Digitalisierung syrischer Handschriften." Oriens Christianus 90 (2006): 210-6.

Kiraz, George Anton. Türrās Mamllā. A Grammar of the Syriac Language, vol. 1 Orthography. Piscataway, NJ: Gorgias Press, 2012.

Lidzbarski, Mark. Die neu-aramäische Handschriften der Königlichen Bibliothek zu Berlin. Weimar: Emil Felber, 1896.

Lieber, Laura S. 2018. Jewish Aramaic Poetry from Late Antiquity. Leiden: Brill.

Littmann, Enno. "Neuarabische Streitgedichte." In Festschrift zur Feier des Zweihundertjährigen Bestehens der Akademie der 
Wissenschaften in Göttingen, II Philologisch-historische Klasse. Berlin: Springer, 1951.

Massé, Henri. “Du genre littéraire 'Débat' en arabe et en persan." Cahiers de Civilisation Médiévale 4: 137-47

Mattock, John N. "The Arabic Tradition: Origin and Developments." In Dispute Poems and Dialogues in the Ancent and Mediaeval Middle Near, ed. Gerrit Jan Reinink and Herman L.J. Vanstiphout. Leuven: Peeters, 1991.

Mengozzi, Alessandro. "A Neo-Aramaic Version of the Soghitha of the Sinful Woman and Satan." In Malphono w-Rabo d-Malphone. Studies in Honor of Sebastian P. Brock, ed. George Kiraz. Piscataway, NJ: Gorgias Press, 2008.

Mengozzi, Alessandro. "Religious Poetry in Vernacular Syriac from Northern Iraq." In Religious Poetry in Vernacular Syriac from Northern Iraq (17th-20th Centuries). An Anthology, CSCO, Scriptores Syri 241, ed. Alessandro Mengozzi. Leuven: Peeters, 2011.

Mengozzi, Alessandro. “'That I might speak and the ear listen to me!': On Genres in Traditional Modern Aramaic Literature.” Journal of Semitic Studies 57:2 (2012): 321-46.

Mengozzi, Alessandro. "Persische Lyrik in syrischem Gewand.Vierzeiler aus dem Buch des Khamis bar Qardahe (Ende 13. Jahrhundert).” In Geschichte, Theologie und Kultur des syrischen Christentums, ed. Martin Tamcke and Sven Grebenstein. Wiesbaden: Harrassowitz, 2014.

Mengozzi, Alessandro. "The Book of Khamis bar Qardahe: History of the Text, Genres and Research Perspectives." In Syriac Encounters. Papers from the Sixth North American Syriac Symposium, Duke University, 26-29 June 2011, ed. Maria Doerfler, Emanuel Fiano, Kyle Smith. Leuven: Peeters, 2015. 
Mengozzi, Alessandro, "Simon Magus and Simon Peter in Rome. The Sureth Version of a Late East-Syriac Hymn for the Commemoration of Saints Peter and Paul." Kervan 22 (2018): 65-90

Mengozzi, Alessandro. "A Sureth Version of the East-Syriac Dialogue Poem of Mary and the Gardener." Kervan, forthcoming.

Mengozzi, Alessandro. 'D'Ahiqar au tapis volant du roi Salomon, des mirabilia géographiques à Sindbad le marin en araméen moderne : adab et recherche orientaliste à la fin du XIXème siècle." In Actes du colloque international "L'adab, toujours recommencé : Origines, transmission et métamorphoses» (Paris, IISMM et INALCO, Jeudi 1er Samedi 3 décembre 2016), ed. Francesca Bellino, Catherine Mayeur-Jaouen, and Luca Patrizi, forthcoming.

Mengozzi, Alessandro. "Neo-Aramaic Dialogue and Dispute Poems. The Various Types." In the proceedings of the international conference Disputation Poems in the Near East and Beyond. Ancient and Modern, held in Madrid 12-13 July 2017, ed. Enrique Jiménez. Berlin: De Gruyter, forthcoming.

Mengozzi, Alessandro. "Syrische Streitgedichte als mündliche Dichtung." In the proceedings of the 10. Deutscher Syrologentag (Berlin, 30/05-2/06 2018), ed. Shabo Talay, forthcoming.

Mengozzi, Alessandro and Luca Basilio Ricossa. "The Cherub and the Thief on YouTube: An Eastern Christian Liturgical Drama and the Vitality of the Mesopotamian Dispute." Annali dell'Istituto Orientale di Napoli 73 (2013): 49-65.

Ong, Walter Jackson. Orality and Literacy. The Technologizing of the Word. New York: Routledge, 1982. 
Parry, Milman. “About Winged Words.” Classical Philology 32 (1937): 59-63.

Pennacchietti, Fabrizio A. "Zmiryata d-rawe: 'stornelli' degli aramei kurdistani." In Scritti in onore di Giuliano Bonfante. Brescia: Paideia, 1976.

Pennacchietti, Fabrizio A. Il ladrone e il cherubino. Dramma liturgico cristiano orientale in siriaco e neoaramaico. Torino: Silvio Zamorani, 1993.

Rand. Michael. 2012. "An Aramaic Dispute between the Months by Sahlan ben Avraham," Melilah: Manchester Journal of Jewish Studies 9: 101-13.

Rodrigues Pereira, Alphons S. Studies in Aramaic Poetry (c. 1000 B.C.E. - c. 600 C.E.). Assen: Van Gorcum, 1997.

Sachau, Eduard. " Über die Poesie in der Volksprache der Nestorianer." Sitzungsberichte der königlich-preussischen Ak. der W. zu Berlin 11:8 (1896): 179-215.

Sachau, Eduard. Verzeichniss der syrischen Handschriften der Koniglichen Bibliothek zur Berlin. Berlin: A. Asher \& Co., 1899.

Wagner, Mark. "The Debate Between Coffee and Qāt in Yemeni Literature." Middle Eastern Literatures 8 (2005): 121-49.

Yaure, L. "A Poem in the Neo-Aramaic Dialect of Urmia." Journal of Near Eastern Studies 16 (1957): 73-87.

Zumthor, Paul. La lettre et la voix. De la "littérature" médiévale. Paris: Éditions de Seuil, 1987. 